\title{
PRACTICING ELECTRONIC EDUCATIONAL RESOURCES IN FOREIGN LANGUAGE TEACHING AT HIGHER EDUCATION INSTITUTIONS
}

\author{
Ramziya Gubaydullina ${ }^{1}$, Elena Dorofeeva ${ }^{2}$ \\ ${ }^{1}$ Teacher, Kazan Federal University, Russian Federation, ramzia.gubaidi@gmail.com \\ ${ }^{1}$ Assoc. Prof. Dr., Kazan Federal University, Russian Federation, elena.dor@mail.ru
}

\begin{abstract}
This article considers the topic of electronic educational resources application in teaching foreign language at higher educational institutions, including e-learning at Kazan (Volga Region) Federal University. It gives a specific example of using such distance learning variant as electronic educational resource, analyzes the students' survey data to find out their opinion on implementation of electronic educational resource in studying special lexis of a foreign language. The aim of the article is to discuss the concept of "electronic educational resources" and analyze their advantages in comparison with other forms and methods of teaching at higher educational institutions when teaching a foreign language. The article shows the relevance of the issue of study due to the large flow of those wishing to learn a foreign language and the introduction of digitalization of education. The practice of electronic educational resources can solve a number of problems and facilitate the process of acquiring knowledge as a self-study, extra classes or when learning is not carried out together with a teacher, under his/her direct supervision.
\end{abstract}

Keywords: teaching, foreign languages, electronic educational resource, electronic learning, linguistics, learners, research, digitalization.

\section{INTRODUCTION}

In today's education, e-learning is a major issue that explains why e-Learning is being actively practiced. Previously, e-learning was perceived as one of the possible forms of knowledge acquisition. Nowadays, the use of information technology and software or other elements of e-learning at higher education institutions is becoming obligatory. Due to the intensive development of information technology, both the educational market and the educational environment in which learning is taking place are changing [1].

\section{Relevance of the Study}

Nowadays, speaking English language is one of the criteria of professional competence required to all the accomplished specialists. With the rapid development of information and communication technologies and the ability to use computer technologies in a professional context has become a real necessity. Therefore, the inclusion of professional vocabulary implemented with the help of electronic technologies in the educational process of future historians is seen necessary for the development of their professional culture. Now it is proved that computer technologies can streamline the process of learning foreign languages and confirms the feasibility of using electronic technologies to enhance the process of learning languages for future specialist in all fields of science and industry. 
As it is known, MOODLE (Modular Object-oriented Dynamic Learning Environment) is an open source web application that provides the ability to create sites for e-learning (electronic courses). The authors of the article developed one of such courses for the students of History Department at KFU which contains the necessary training, support and control materials and methodical instructions (for students and teachers) in accordance with the syllabus of the discipline.

The aim of this study is to provide a theoretically proved, experimentally tried and relying on modern linguistic research method of teaching ESP to students of History Department with the use of electronic resources.

\section{METHODS}

Along with other higher education institutions, Kazan (Volga Region) Federal University (KFU) widely uses elearning resources or electronic educational resources (EERs) in the educational process. The aim of elearning implementation is to improve the quality of education through active learning methods and individualization of academic paths.

For the subjects taught as part of KFU educational programmes, e-learning resources allow students to familiarise themselves remotely with the content of the discipline at a level sufficient for its successful mastering, provide an opportunity to provide independent work for students, familiarise them with additional sources on a particular discipline, etc.

In foreign language classes at higher education institutions, as shown by analysis of the relevant literature, it is advisable to use a combination of traditional and modern methods of teaching a foreign language for the greatest efficiency of mastering knowledge. Diversity and flexibility of skillful variation of teaching methods contribute to enhancing cognitive activity of students, which is of no small importance, the main thing is to find the right balance [2]. Based on this, practicing electronic educational resources is best suited in the teaching of foreign languages at higher education, as one of the effective ways of gaining knowledge, contributing to the quality of learning, using world educational resources, increasing the proportion of independent learning material, ensuring the development of such features as independence, responsibility, organization, the ability to realistically assess their strength and take informed decisions [1].

The term "Electronic Educational Resources" (EERs) is the most general term for learning tools developed and delivered using computer technologies. In general, e-Learning resources are educational materials that are reproduced using electronic devices.

An electronic resource may be presented as a textbook, workbook, teaching guide, self-study manual, practical work, etc.

When developing and implementing electronic educational resources in the educational process, general requirements for their use should be taken into account. Modern digital educational resources should:

1) Correspond to the content of the textbook, regulatory acts of the Ministry of Education and Science of the Russian Federation, and the programmes used;

2) Be oriented to modern forms of education, provide highly interactive and multimedia teaching and training;

3) Provide an opportunity for the level differentiation and individualisation of learning;

4) Offer the types of learning activities orienting the learner to acquire experience in solving life problems on the basis of knowledge and skills within the subject;

5) Ensure the use of both independent and group work; contain variants of learning planning that assume a modular structure;

6) Exceed the volume of relevant sections of the textbook, without extending the thematic sections;

7) Be fully reproducible on declared technical platforms;

8) Enable other programmes to be used together with digital learning resources;

9) Where methodologically feasible, provide customization and storage of intermediate results;

10) Have, where appropriate, built-in contextual help;

11) Have a user-friendly interface [6].

An analysis of the relevant literature describing the experience of implementing electronic educational 
resources in education has shown that the use of these resources has both advantages and disadvantages. The advantages of electronic resources include the following:

1) Learning material is considered as a complex and all constituent parts of the education process are provided;

2) Students can receive information as well as they can independently study the material, do practical assignments, undergo grading and monitor learning while studying the material;

3) The learning process becomes more dynamic;

4) It becomes possible to store large scopes of information;

5) Due to EERs, students can study not only with a teacher, but also independently;

6) The use of various multimedia forms of learning provides interactivity of learning [7].

7) Students who have missed classes due to health reasons can master the material in a short time on the basis of Moodle distance learning.

Having considered the advantages of ELRs in the educational process and based on the experience of their usage at higher education institutions, we can say that the practicing electronic educational can significantly improve the quality of learning, and the effectiveness of using ELRs, as emphasised in the relevant literature, leads to the following indicators:

1) Students are more interested in the subject;

2) The quality of learning is significantly improved;

3) Individualisation of the educational process;

4) Students obtain additional information on the subject [4].

The main disadvantages of the use of electronic educational resources, as shown by the analysis of relevant literature, include:

1) Course limitations;

2) Time consuming to create and update a course

3) Impossibility of modification;

4 Likely legal problems associated with intellectual property protection;

5) Personnel problems associated with the training of teachers able and willing to develop and constantly update such courses [6].

There are also factors that reduce the quality of EERs, that many teachers consider to be

- The imperfect practicing of the full potential of electronic resources;

- A poor technical support;

- The inconsistency between EERs and the course content;

- The time limitation to create high-quality EERs;

- Psychological barriers of teachers [3].

Among other things, a certain number of teachers have noted that the student's self-study leads to a reduction in the quality of learning, because computers and the Internet cannot fully replace the teacher.

Having carefully studied and analysed all the features of implementation in the educational process at higher education institutions of such form of learning resources as electronic educational resources (EERs), and having considered the pros and cons of using such resources, we have developed our own electronic educational resource in the English Language "History of Imperial Russia".

The basis of e-learning system is LMS MOODLE (Modular Object-Oriented Dynamic Learning Environment open-source learning management system) [5]. Electronic educational resource "History of Imperial Russia", offered by us, is intended for students learning at the department "Russian (National) History". The course contains materials for study in this specialty supplementing the main course of the English language. This EER is for undergraduates, graduate students and those interested in the political situation and problems of 
Russia during the reign of the Romanovs' dynasty. The aim of the electronic resource is to introduce Englishlanguage texts to students. It corresponds to the level of knowledge received in History, broaden their horizons and contain communicatively relevant linguistic material. This electronic resource allows to combine professional training for students with a basic English language level. Reading and translation skills and vocabulary within their field of study are essential for both their academic and professional activities.

The electronic educational course consists of 6 Modules:

1. Peterthe Great.

2. Elizabeth of Russia.

3. Catherine the Great.

4. Alexander I.

5. Alexander II.

6. Nicholas II.

Each Module includes:

1) A video or audio to introduce the topic of the e-learning resource and to broaden knowledge of the proposed topic.

2) Two texts for introducing, searching or abstracting that depends on the specifics of the text.

3) Seven exercises to the texts aimed at understanding the texts, developing vocabulary skills as well as exercises of prepared speaking with the use of speech samples, information from the text and free speaking based on the material of certain topics to be studied in the class.

4) Wiki (the Wiki module - allows participants to add and edit a set of linked web pages), where students can not only add their answer to a given question to a group Wiki page, but can also rate each other's answers.

5) A forum where discussion questions are provided for students to prepare answers to be presented to the class in class at the instructor's request.

6) An end-of-module test to check how well the module topic is understood.

7) A final test.

We carried out a study (an experiment) to determine students' attitudes to electronic educational resource when learning English vocabulary through questionnaires, observations, conversations in order to establish the reasons for negative impressions of its use and to identify students' perceptions of such a method of knowledge acquisition as the e-learning. This, in turn, made it possible to assess the productivity of this method in the learning process in the most accurate way. Students' opinions on the course, the views of elearning participants, and their results play an important role for us in evaluating the effectiveness of practicing this method in their classes. We cannot ignore the fact that when students perceive the work as an enjoyable experience, enjoy the amount of work they have personally done, they tend to interact more that improves learning outcomes. The survey was administered to second-year students of the Institute of International Relations at Kazan Federal University majoring in Russian (National) History and History of Turkic Peoples, during the semester of the 2016-17 academic year. The questionnaire contained five questions and three answer options: 1) "yes", 2) "no", 3) "difficult to answer". Before the survey, all signed up students were explained how to fill in the questionnaire. The respondents received questionnaires during the classes after which the questionnaires were collected. The findings of the questionnaire were analysed for the final result and conclusions.

\section{RESULTS}

This research is based on the method of collecting personal data and questions. Thirty-nine students (12 male and 27 female students) learning English at Pre-Intermediate level were interviewed to give their opinion on the acquisition of professional vocabulary in English online, through the electronic educational course "History of Imperial Russia". The results are presented in Tables 1 and 2. 


\section{Table 1}

Boys aged 19 (8), boys aged 20 (4)

A total of 12 people were polled

\begin{tabular}{|l|l|c|c|c|}
\hline \multicolumn{1}{|c|}{ Мнение участников } & Yes & NO & $\begin{array}{c}\text { Difficult to } \\
\text { answer }\end{array}$ \\
\hline 1 & $\begin{array}{l}\text { Electronic educational course "History of Imperial Russia" is } \\
\text { compelling in terms of content }\end{array}$ & 12 & \\
\hline 2 & $\begin{array}{l}\text { Electronic educational course "History of Imperial Russia" is } \\
\text { logically constructed }\end{array}$ & 9 & 2 & 1 \\
\hline 3 & $\begin{array}{l}\text { Electronic educational course "History of Imperial Russia" is } \\
\text { useful for mastering ESP }\end{array}$ & 11 & 1 \\
\hline 4 & $\begin{array}{l}\text { Electronic educational course "History of Imperial Russia" is } \\
\text { essential in the learning process }\end{array}$ & 6 & 1 & 5 \\
\hline 5 & Would you like to continue e-learning ( EER) next year & 7 & & 5 \\
\hline
\end{tabular}

\section{Table 2}

Girls aged 18 (1 person), girls aged 19 (12 people), girls aged 20 (12 people), girls aged 21 (2 people)

A total of 27 people were polled

\begin{tabular}{|l|l|c|c|c|}
\hline \multicolumn{1}{|c|}{ Мнение участников } & Yes & No & $\begin{array}{c}\text { Difficult to } \\
\text { answer }\end{array}$ \\
\hline 1 & $\begin{array}{l}\text { Electronic educational course "History of Imperial Russia" is } \\
\text { compelling in terms of content }\end{array}$ & 24 & 1 & 2 \\
\hline 2 & $\begin{array}{l}\text { Electronic educational course "History of Imperial Russia" is } \\
\text { logically constructed }\end{array}$ & 24 & 3 \\
\hline 3 & $\begin{array}{l}\text { Electronic educational course "History of Imperial Russia" is } \\
\text { useful for mastering ESP }\end{array}$ & 24 & 3 & 8 \\
\hline 4 & $\begin{array}{l}\text { Electronic educational course "History of Imperial Russia" is } \\
\text { essential in the learning process }\end{array}$ & 16 & 3 \\
\hline 5 & Would you like to continue e-learning ( EER) next year & 15 & 4 & 8 \\
\hline
\end{tabular}

On the whole, the findings of the survey show students' satisfaction and interest in practicing of EERs in the learning process. This is evidenced by their answers to questions $1,2,3$. Regarding questions 4 and 5 , we can see that male and female students have different attitudes towards E-Learning in English for Specific Purposes (ESP). The percentages are as follows: $59 \%$ of girls think that EERs are necessary in the learning process, while the share of boys is lower and equals $42 \%$. Eleven per cent of girls and 8 per cent of boys do not think that it is worthwhile to use the resource; 30 per cent of girls and 42 per cent of boys do not know what to say. Fifty-six per cent of girls and 58 per cent of boys would like to continue using electronic educational resources. There are no strong opinions about e-Learning resources among the girls whereas the figure for girls is $15 \%$. Thirty per cent of girls and 42 per cent of boys found it difficult to answer

\section{CONCLUSIONS}

Our research allowed us to evaluate students' attitudes towards the practicing of electronic educational 
resource in teaching English for Specific Purposes (ESP). The results showed students' satisfaction with online learning, they found it informative and engaging, they were able to learn new educational tools and apply them in practice thanks to the e-resource. Students indicated that the use of e-learning materials gave the best learning outcomes compared to traditional learning. During the study, we have seen that acquiring new knowledge in this way helps students to improve their language skills, makes the process of learning a foreign language interactive, interesting and makes it effective and productive for students to work together with the teacher and with each other. Students are also able to take responsibility for their own learning process and decide for themselves where and when to carry out these tasks.

Thus, to summarise the above, it can be said that practicing of electronic resources in foreign language classes is essential and beneficial and the knowledge gained in this way will be remembered much better and stored in memory for a longer time.

\section{REFERENCE LIST}

1. Glavatsky S. T., Mikhalev A. V. E-Learning Technologies: Experience of Lomonosov Moscow State University / Electronic Information Systems № 3 (10) 2016. pp. 39-44

2. Dorofeeva E.V. Didactic conditions and criteria for the development of students' creative potential in elective classes in humanities subjects: dissertation... Pedagogical Sciences / E.V. Dorofeeva; Kazan. State. Univ. - Kazan, 2006. - 312 P.

3. Khafizov I.I. Quality Management System in Higher Education Institution as a Tool for Competitiveness [Electronic resource] / Kazan: KNRTU, 2012. Access mode: http://repository.kpfu.ru/?p_id=55232.

4. Khafizov I.I. Stages and difficulties of implementing the elements of quality management system in educational institution of higher professional education [Electronic resource] //.Kazan: KNRTU, 2012. - № 7. Access mode: http://www.kstu.ru/article.jsp?id=1910\&id_e=23840\&.

5. "History of Imperial Russia" electronic educational resource: http://edu.kpfu.ru/course/view.php?id=1656

6. Satunina A.E. E-learning: pros and cons // Modern problems of science and education. Series Pedagogical and Social Sciences. 2006. № 1. pp. 89-90.

7. Osetrova N. V. Book and electronic media in education. - Moscow: Publishing service Logos, 2003. - 144 $P$. 